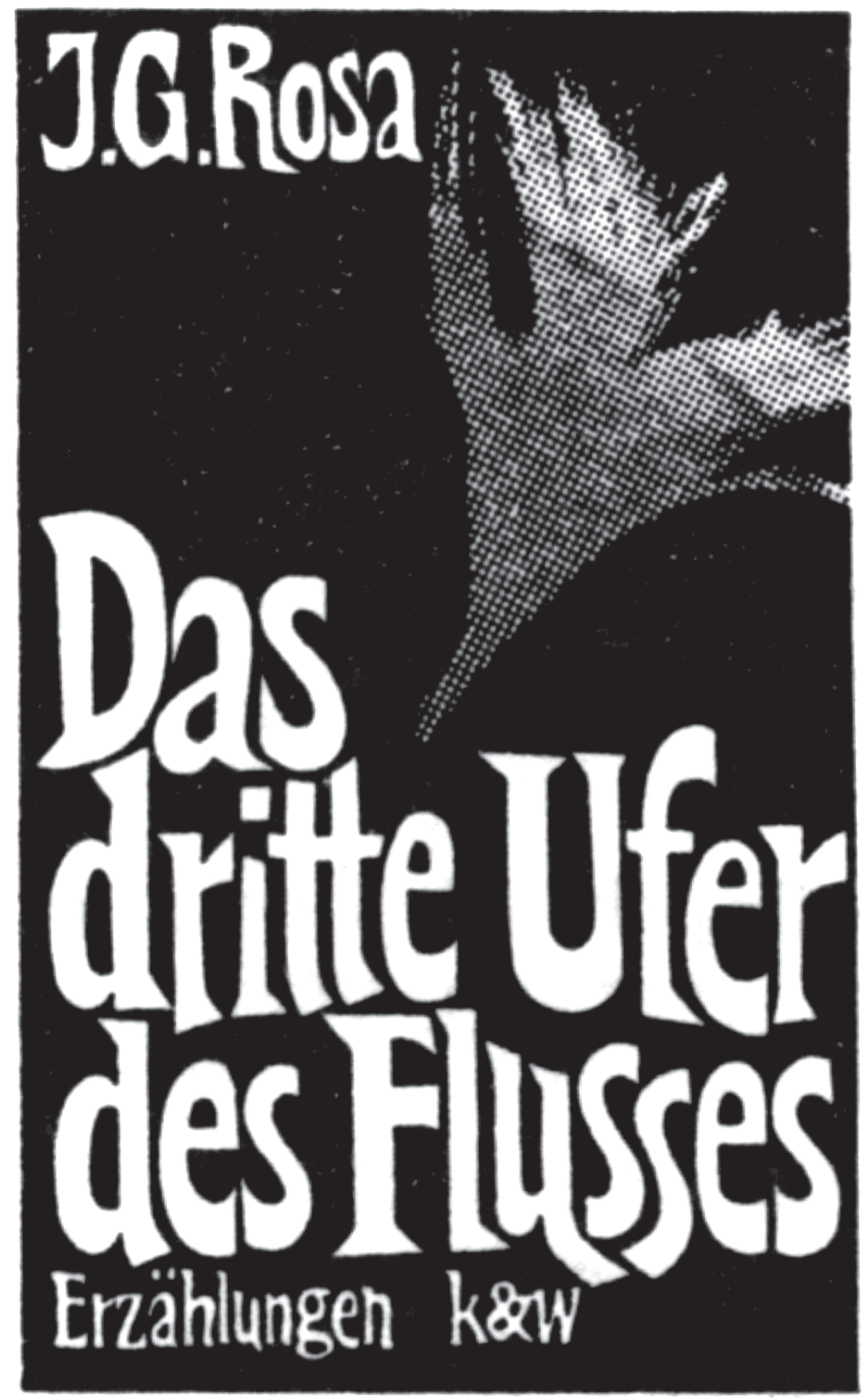

Capa da edição alemã de Primeiras Estórias à qual deu título o conto "A Terceira Margem do Rio" 


\section{“A TERCEIRA}

\section{MARGEM DO RIO”}

\section{Fluxo do tempo e paternidade}

em Guimarães Rosa (com reflexões

em Drummond de Andrade)

ELIDE V. OLIVER

é professora da University

of Minnesota (EUA).

“..QQue río es éste

por el cual corre el Ganges?

Que río es éste cuya fuente es inconcebible?

Que río es éste

que arrastra mitologías y espadas?

Es inútil que duerma.

Corre en el sueño, en el desierto, en un sótano.

El río me arrebata y soy ese río.

De una materia deleznable fui hecho, de misterioso tiempo.

Acaso el manantial está en mí.

Acaso de mi sombra

surgen fatales y ilusorios, Ols días”

(“Heráclito”, Jorge Luis Borges). 


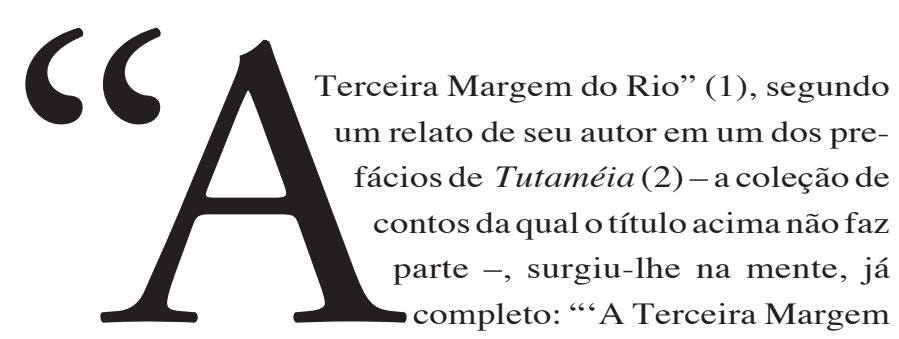

do Rio’ veio-me, na rua, em inspiração pronta e brusca, tão 'de fora', que instintivamente levantei as mãos para 'pegá-la' como se fosse uma bola vindo ao gol e eu o goleiro" (p. 680).

Embora a experiência de totalidade como insight não seja incomum a artistas, escritores ou cientistas, no caso de Rosa parece que o comentário acrescenta continuidade a um dos temas envolvidos na própria história, como veremos a seguir. É digno de nota, também, que a confissão tenha aparecido anos mais tarde, em 1967, no meio de um dos prefácios da mais hermética coleção de contos que Rosa jamais escreveu: Tutaméia. No glossário que acompanha o último dos quatro prefácios do livro, lemos: "tutaméia: nonada, baga, ninha, inânia, ossos-deborboleta, quiquiriqui, tuta-e-meia, mexinflório, chorumela, nica, quase-nada; mea omnia" (p. 687). Mea omnia ... tudo meu...tutomeu, numa forma inventada e inventiva passada ao feminino: tutaméia. Se tutaméia é o tudo-meu, é também nonada, bagatela. Nonada, como sabem os leitores de Rosa, é a palavra que abre o monólogo de Grande Sertao: Veredas, a palavra que põe em moção o rio-monólogo de Riobaldo, narrador da batalha entre o Bem e o Mal no sertão.

\section{A SUBSTÂNCIA NADA DO NADA}

Tutaméia é também "quase-nada". É, portanto, ossos-de-borboleta, boa metáfora do minimal, ícone do nada já que sendo invertebrada a borboleta não possui ossos.

João Guimarães Rosa, "A Terceira Margem do Rio", in Primeiras Estórias, Ficção Completa, vol. II, Rio de Janeiro, Nova Aguilar, 1995.

2 Idem, Tutaméia. de-borboleta. Alguns títulos da coletânea lêem: "O Outro ou o Outro"; "Antiperipléia"; "Hiato"; "Uai, Eu? Sinhá Secada". Tais títulos serão pistas, indícios de que estamos perto do nada residual, expresso nas mínimas definições da palavra tutaméia. Aqui a intenção é a de chegar à idéia do nada por extração, como o próprio autor coloca, no primeiro prefácio, “Aletria e Hermenêutica”, onde, como exemplo da residualidade do nada, Rosa desenvolve a seguinte imagem: "O nada é uma faca sem lâmina da qual se tirou o cabo...” (p. 521).

Esse nada, como se lê na definição, não tem uma natureza niilista, entretanto. É muito mais o gato preto que nao está na sala escura quando o homem de olhos vendados o procura, outra alegoria do nada tirada do mesmo prefácio e inspirada em Voltaire. Para se chegar à conclusão de que não há nada no quarto escuro, devemos primeiro buscar. É a busca que importa, porque só ela é capaz de operar uma mudança de percepção nos objetivos do buscador. E isso só pode ocorrer no devido tempo, isto é, depois que a busca se revela, num insight, desnecessária. É preciso que um determinado tempo transcorra para que essa busca se revele "inútil" e ao se revelar "inútil" acabe desvendando a sua própria utilidade, agora em outro nível. O gato preto da primeira busca vira o nada da busca final. Esse nada, portanto, não carrega nenhuma característica pessimista ou aniquilatória. Ele é antes uma descoberta, um desvendamento do verdadeiro Ser através da retirada das várias camadas acumuladas pela retórica das imagens reunidas à sua volta (o gato preto na sala escura e o homem vendado). Só com o desvelamento no devido tempo da percepção do nada vai revelar-se o Ser em sua autenticidade.

"A Terceira Margem do Rio" é uma história que está essencialmente envolvida nesse processo de retirada e desvendamento. A narrativa é tecida no mais próximo de um imitativo baixo que o estilo de Rosa permite. Sua dicção atém-se a dar o mínimo de informação necessária, atém-se ao essencial, como que exigindo do leitor uma concentração máxima no absurdo da 
história. Quanto ao assunto, temos um pai, um homem de quem vão sendo retiradas gradualmente as condições de pai e de homem até que o que sobre seja um resto sozinho, afastado numa canoa no meio de um rio, dias e noites, meses e anos a fio. $\mathrm{O}$ que significa o tempo para esse homem? Como esse tempo o afeta? Será que o ato da canoa constitui uma revolta contra o tempo, um desafio às suas leis, um colocar-se fora de seu alcance? Ou, bem ao contrário, é uma decisão de enfrentar a sua hora antes mesmo que ela chegue? O que é esse rio do qual se diz que há uma terceira margem?

Tentando abordar essas questões melindrosas, encontramos as palavras do autor numa entrevista:

"Escrevendo, descubro sempre um novo pedaço de infinito. Vivo no infinito; o momento não conta. Vou lhe revelar um segredo: creio já ter vivido uma vez. Nesta vida, também fui brasileiro e me chamava João Guimarães Rosa. Quando escrevo, repito o que vivi antes. E para estas duas vidas um léxico apenas não é suficiente. Em outras palavras, gostaria de ser um crocodilo vivendo no rio São Francisco. O crocodilo vem ao mundo como um magister da metafísica, pois para ele cada rio é um oceano, um mar de sabedoria mesmo que chegue a ter cem anos de idade. Gostaria de ser um crocodilo porque amo os grandes rios, pois são profundos como a alma do homem. Na superfície são muito vivazes e claros, mas nas profundezas são tranqüilos e obscuros como os sofrimentos do homem. Amo ainda mais uma coisa de nossos grandes rios: sua eternidade. Sim, rioéuma palavra mágica para conjugar eternidade" (3).

Essas palavras ajudam a iluminar muitos elementos de "A Terceira Margem do Rio": o infinito e o eterno, a alegoria do rio e do homem, o papel da lembrança, do rememoramento, no sentido platônico, e a possibilidade, metafórica, da transmigração de almas, operando um nexo entre esquecimento (ou escondimento) e lembrança (ou revelação), como a forma de existência do Ser através de suas muitas vidas.

\section{DO COLETIVO E DO INDIVIDUAL}

A história da terceira margem começa com a narração do filho sobre nosso pai. A voz plural do narrador: "Nosso pai era homem cumpridor, ordeiro, positivo" ( $p$. 409) introduz uma noção de coletividade que acaba por incentivar um certo número de associações. Uma das quais é a noção do pai coletivo primordial, o senhor do clã. Essa hipótese da antropologia novecentista (Frazer entre outros) foi redimensionada pela teoria freudiana sobretudo com relação aos aspectos da culpa que sentem os assassinos do pai na horda primitiva, depois que o matam. Freud (4) ao tentar entender a questão da culpabilidade do filho em relação a seu pai, procura ligar esse sentimento ao triângulo familiar edípico: o filho que deseja inconscientemente a morte do pai porque deseja a mãe, daí a culpabilidade consciente. Entretanto, os aspectos ditos mais primitivos desse arranjo também incluem uma rebeldia contra a autoridade estabelecida, sobretudo quando esta autoridade é sentida como arbitrária, uma luta de poder em vários níveis: os mais novos contra os mais velhos, o grupo contra o indivíduo, etc. Desnecessário dizer que o tema do assassínio do pai faz figura principal em várias mitologias também; os mitos gregos, por exemplo, oferecem uma gênese de assassinatos paternos, com Urano sendo morto por Cronos e por sua vez sendo destronado por Zeus.

Morte e culpabilidade estão intimamente ligadas no relacionamento do pai primitivo com seus filhos, mas fazem parte das ambigüidades inconscientes ou não de qualquer relacionamento entre pai e filho.

A forma coletiva do narrador também contribui, além das nuances apontadas acima, para dar à história um status de relato objetivo e consensual, uma idéia de que havia um acordo naquela família a respeito da estranheza da atitude do pai e, portanto, um filho tinha autorização para escrever em nome de todos. Com certeza, os eventos relatados pelo narrador afetaram e transformaram definitivamente as vidas
3 Idem, "Diálogo com Guimarães Rosa", in op. cit., vol. I, entrevistador, Günter Lorenz.

Sigmund Freud, principalmente Totem e Tabu, edição standard, Rio de Janeiro, Imago. 
de todos na família. Aqui se percebem várias realidades duais se desenvolvendo no conto. A realidade dual aqui representada pelo coletivo e pelo individual incorporados na narrativa filial vai ser apenas mais uma das outras realidades duais chamadas a representar um papel nessa história.

Uma outra dualidade será representada pela historicidade do homem contra a eternidade do rio. A individualidade humana representa o ser histórico, mortal, aquele que nasce, vive sua vida individual e morre, o assim chamado ser-para-a-morte. Esse ser não escapa do tempo e não pode se colocar a salvo dele, ou acima ou abaixo dele pois estaria se colocando acima ou abaixo ou além da própria morte. O homem individual é, portanto, descontinuidade temporal onde o rio do tempo é continuidade pois nunca pára. Mas o que fazer do eterno?

\section{DO REMEMORAMENTO E DO ESQUECIMENTO}

O papel do rememoramento, da lembrança ..."Do que eu mesmo me alembro" (p. 409) no sentido platônico é outra chave da história, estando ligada à memória coletiva da espécie humana e à memória individual do ser histórico. Essa lembrança (e seu correlativo esquecimento) está ligada à fragilidade e à descontinuidade da memória humana quando medida contra o eterno fluxo do tempo representado pelo rio. Lembrar é estar vivo, é estar na superfície do rio, como nas palavras de Rosa na entrevista.

A superfície é onde o rio do tempo toca a canoa da individualidade humana. A vida individual que podemos lembrar antes de cruzar o rio do Esquecimento (Letes). O rio que aniquila a memória individual e conduz o ser-para-a-morte para a sua reunião com o Uno. Assim, o Rio é ao mesmo tempo o rio da vida e o rio da morte, da lembrança e do esquecimento, aletheia e lethes. O morto, quando levado por Caronte, primeiro cruza o rio lethes e deixa para trás, esquecida, sua vida passada, antes de alcançar as águas do Estige e finalmente as margens do Hades.

Renascer, para Platão, é trazer a possibilidade de rememoramento de todas as coisas passadas e aprendidas nas vidas prévias. O Uno se divide então de novo na multiplicidade e o processo temporal recomeça.

Nosso narrador não pode esquecer do dia em que a canoa ficou pronta: "E esquecer não posso, do dia em que a canoa ficou pronta" (p. 409), pois esse dia foi o último dia em que um claro acontecimento ocorre com relação ao pai. Depois desse dia, como se o tempo parasse, havia apenas o pai na canoa. As correntes subterrâneas de tempo e de eternidade, vida e morte, lembrança e esquecimento estão sempre em movimento nesse relato filial. O relato que fala de um homem que depois de ser descrito como normal decide mandar fazer uma canoa e uma vez esta pronta dá adeus à família, entra nela e rema até o centro do largo rio da vizinhança e passa o resto de seus dias ali sozinho.

A canoa foi feita especialmente para ele: "Encomendou a canoa especial, de pau de vinhático, pequena, mal com a tabuinha da popa, como para caber justo o remador. Mas teve de ser toda fabricada, escolhida forte e arqueada em rijo, própria para dever durar na água por uns vinte ou trinta anos" (p. 409). O tamanho dessa canoa, "como para caber justo o remador", oferece uma tentadora similaridade com um caixão. Para a morte vai o pai, sozinho, nessa jornada, pois é sozinhos que enfrentamos a morte, todos.

\section{DOS RIOS E DA MORTE}

O filho pergunta ao pai se pode ir junto: "Pai, o senhor me leva junto, nessa sua canoa? Ele só retornou o olhar em mim, e me botou a bênção, com gesto me mandando para trás" (p. 409). Morrer, tanto quanto nascer, é um ato solitário. Não há levar 
junto. Mas a ação inexplicável do pai-como a morte de pessoas que amamos sempre parece gratuita e inexplicável-formará um desejo de partilha no filho. Concebendo a idéia de que ele pode, de alguma forma, substituir o pai nesse projeto aparentemente absurdo, o filho tenta repartir o fado, somente para fracassar e desencadear um permamente sentimento de culpa. Sua falha nasce de sua incapacidade de captar o impossível de sua tarefa. É possível para o filho tomar o lugar do pai e sacrificar-se a si próprio em seu lugar?

Em termos de espécie, da constante ciclicidade biológica, com os seres nascendo e morrendo, pode-se dizer que para a natureza tanto faz quem nasce ou morre. Essa é a perspectiva do Eterno com relação ao mortal. Sob o ponto de vista de uma natureza em permamente variedade biológica não importa quem nasce ou morre. O constante nascimento e perecimento dentro das espécies, pelo contrário, possibilita uma idéia de substituição, visto que a individualidade pouco importa, o gato ou a rosa que nasce hoje em nada difere, em termos de espécie, dos gatos e rosas de cinqüenta, cem ou mil anos atrás. A indiferença da assim chamada Natureza é tão grande que nem mesmo a sobrevivência de espécies inteiras tem garantia e sabemos que muitas delas foram extintas. Assim, em termos estritamente biológicos, em termos de espécie, esse filho pode substituir seu pai na canoa, assim como qualquer outro ser vivo sobre a terra.

Mas o filho, como indivíduo, com seu próprio destino, sua própria história, não pode tomar o lugar do pai nessa canoa. Por isso ele foge. Sua hora ainda não chegou. O conflito entre individualidade e coletividade dentro da figura do filho é bem representado por sua hesitação. Como representante da espécie ele poderia tomar o lugar do pai, como indivíduo não pode substituir sua própria sorte. A falha do filho em entender isso é a origem de seu conflito.

Em termos de individualidade, portanto, o gesto do pai - aliás o único em tantos anos - pode ser visto como sendo um gesto de aceitação; a aceitação do sacrifício voluntário do filho. Mas esse filho não é Cristo, que era deus e humano e, portanto, carregava o individual e o coletivo em si. Esse filhoé apenas humano e sendo humano falha em seu resgate.

Há duas questões aí, uma lidando com a inevitabilidade do último encontro com a morte, que engloba tanto o indivíduo enquanto tal como enquanto espécie - todo o mundo é um ser-para-a-morte. A outra envolvendo o problema do destino pessoal face à morte. Tudo isso para dizer que mesmo sendo seres-para-a-morte, ainda assim, cada um de nós tem a sua própria hora, segundo sua história pessoal. Nosso narrador intui isso embora seja incapaz de articular o conflito. Essa é a razão pela qual ele oferece e depois retira sua vida nesse sacrifício, pois sua hora ainda não havia chegado.

\section{DO RESGATE}

Aqui o contraponto com uma atitude crística deve ser notado. O sacrifício de Cristo foi ao mesmo tempo voluntário e determinado. Ele ofereceu-se em sacrifício mas não pôde escapar do gosto amargo do cálice, tendo que beber até a sua última gota. Não pôde ser preso ou molestado antes que a sua hora tivesse chegado, ou seja, antes que se desse o completamento de sua experiência individual na terra com a morte.

O filho, na história de Rosa, não pode dar-se em sacrifício, seja voluntário ou compulsório pois, diferentemente de Cristo, sua vida não the pertence. Ele carrega, entretanto, depois do resgate falhado, as marcas de seu fracasso, para o resto da vida, como se sua involuntária "escolha" em não tomar o lugar o dragasse para um permanente estado de não-ser: "Sou homem, depois desse falimento? Sou o que não foi" (p. 412). Ele apenas tem diante de si a possibilidade escassa de ser o ser que não foi no momento em que devia ser. Essa inconsistência essencial o conduz à morte em vida, corroendo-o por dentro, transmudando o seu ser em não-ser: "temo abreviar com a vida" (p. 412). 
Por trás do não-ser está o medo, o intenso medo que sentiu quando viu o pai fazendo o temido gesto de aceitação, pois the pareceu que seria a aceitação da própria morte: "Porquanto que ele me pareceu vir; da parte de além. E estou pedindo, pedindo, pedindo um perdão" (p. 412).

O rio envolve o pai e o filho no mesmo enigma. O pai representa o enigma da questão sem resposta que é a morte. Ele se torna a metáfora da ausência flutuando no rio do perpétuo movimento do tempo que corre indiferente às manifestações de Capa da edição espanhola historicidade individual, que somos nós: "Se o meu pai, sempre fazendo ausência: e o rio-rio, o rio - pondo perpétuo" (p.412).

\section{JOÃO GUIMARÃES ROSA}
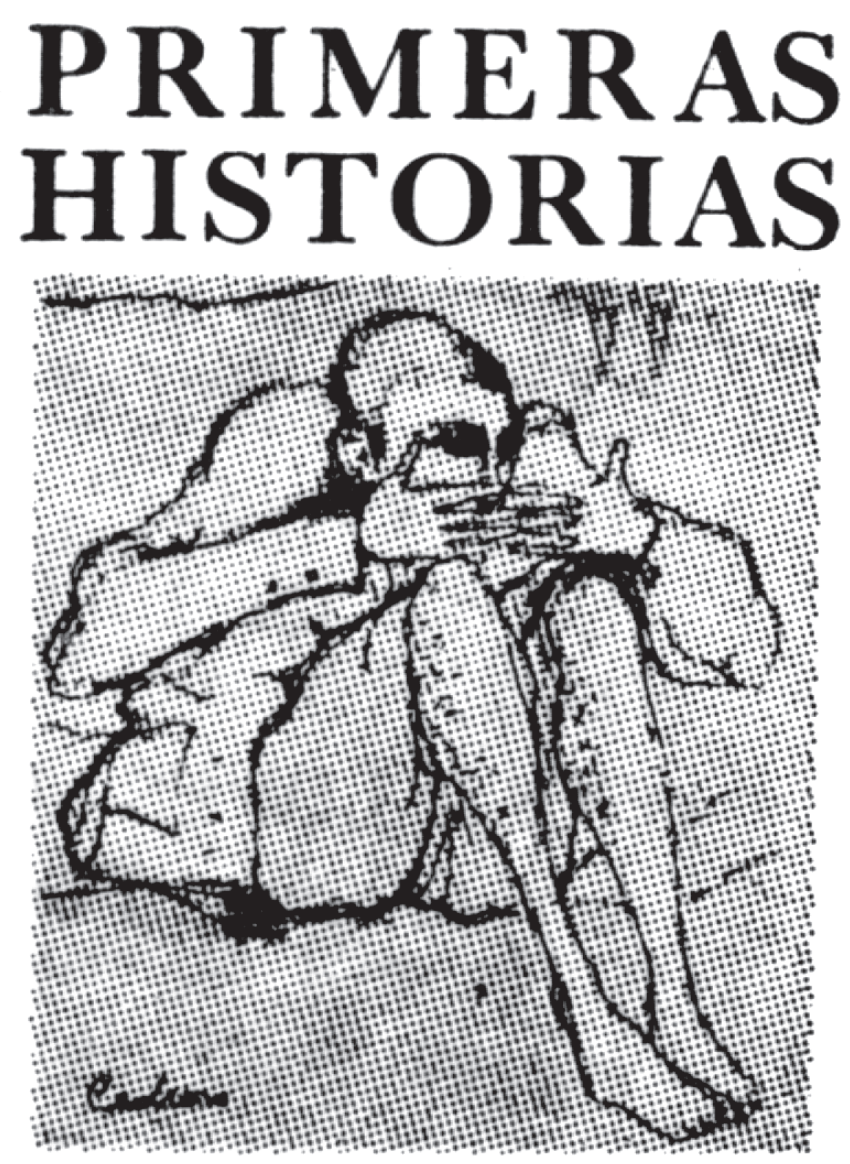

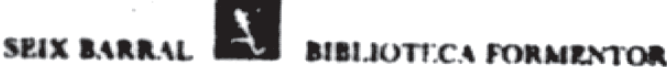

O filho capturado nesse enigma não pode perceber que a ausência do pai representa a própria morte. O filho ainda está no momento de busca, naquele quarto escuro, pensando que o gato preto ainda está lá. O mesmo tempo que nos conduz à morte nos conduz à percepção, passado um tempo, que nos permite transcender a dor da morte nessa busca metafísica ou mística. O filho assim capturado persiste na busca de um entendimento do absurdo da situação pensando que se trata de um ato voluntário praticado por esse ser histórico e individual que é ou era o seu pai. O que o paralisa é a mágoa de achar que se trata de um ato de escolha voluntariamente feito pelo pai, num certo ponto de sua vida.

Conceber o absurdo do ato do pai como resultante de uma escolha individual é um erro que levará a outro erro similar: causará no filho um falso senso de escolha que, como vimos, consiste na proposta de substituição: "Pai, o senhor está velho, já fez o seu tanto... Agora, o senhor vem, não carece mais... O senhor vem e eu, agora mesmo, quando que seja, a ambas vontades, eu tomo o seu lugar, do senhor, na canoa!...” (p. 412). Mas não pode haver acordo "a ambas vontades" porque essas vontades não convergem. São paralelos que jamais se encontrarão. “Ambas vontades" nessa circunstância de extrema individualidade não têm poder para estabelecer contrato, pois ocampoondeestas vontades se manifestam é o destino individual e sua hora. $\mathrm{O}$ motivo individual do pai para estar na canoa está explicitado na voz do filho, que diz o que ainda não pode compreender: "Pai, o senhor está velho, já fez o seu tanto...", ele enuncia mas não entende o que diz, que é a verdade de que o velhohomem cumpriu seu destinoindividual e pronto está.

O filho, ao não entender as impossibilidades presentes nessa falsa troca, persiste na aparente voluntariedade de ambos os atos, de pai e filho, e isso alimenta, se é que não causa, a sua culpa.

O exíguo compartimento da canoa não pode ser partilhado. Ele pertence a um destino individual e esse destino não pode ser mudado por contrato de vontades. O 
Tempo, sob essa disposição individual, é o tempo da História, a sucessão cronológica de eventos compreendidos entre um começo e um fim. Normalmente o senso de destino, os "dias contados", é um pensamento que ocorre a posteriori, postfacto, e serve, quando muito, para injetar sentido naquilo que é definitivamente o acaso de estarmos vivos.

Além disso, o tempo individual permite que tudo o que ocorre para um indivíduo entre seu nascimento e sua morte adquira uma linearidade histórica acompanhada de uma lógica, seja ela factual, psicológica, social ou outra que ordene o acaso numa linhagem passível de sentido. Tais eventos são vividos pelo indivíduo como únicos e irrepetíveis. Mais uma razão para que a ocorrência na canoa seja pessoal e intransferível.

A situação de se colocar um homem solitário selado numa canoa no meio de um rio simboliza a própria condição existencial humana. A deficiência do filho em entender essa condição básica como sua condição também propicia material para o seu senso de culpa nascido de sua falha em substituir o pai em sua canoa. O flerte com a possibilidade de suicídio procura restabelecer algo de natureza voluntária numa situação em que tudo parece involuntário e caótico: "Sei que agora é tarde, e temo abreviar com a vida, nos rasos do mundo" (p.413). Depois de falhar e tornar-se um não-ser: "Sou o que não foi” (p. 413), também ele deseja a sorte do pai na canoa. "Mas então, ao menos, que no artigo da morte, peguem em mim, e me depositem também numa canoinha de nada, nessa água, que não pára, de longas beiras: e eu, rio abaixo, rio afora, rio adentro - o rio" (p. 413). A canoa da morte é uma "canoinha de nada" reforçando o nada da morte em contraste com a presença eterna do rio, de longas margens, abaixo, afora, adentro. Porém, nessa canoinha de nada há algo de tutaméia, do nada residual, que, em última instância, pode estabelecer uma fusão entre o eterno fluxo do tempo do rio e a nonada desse ser que é o que não foi, restabelecendo-o em unidade, salvando-o da aniquilação definitiva do nada abismal.

\section{DE RIOS E DA ETERNIDADE}

A oposição entre os "rasos" do mundo e as profundezas do rio é digna de nota: “o rio por aí se estendendo grande, fundo, calado que sempre. Largo, de não se poder ver a forma de outra beira" (p. 409). Essa oposição está virtualmente presente também na entrevista de Rosa que reproduzimos acima. Ali, também a imagem de um crocodilo aparece: "Gostaria de ser um crocodilo vivendo no rio São Francisco. O crocodilo vem ao mundo como um magister da metafísica, pois para ele cada rio é um oceano, um mar de sabedoria mesmo que chegue a ter cem anos de idade. Gostaria de ser um crocodilo porque amo os grandes rios, pois são profundos como a alma do homem. Na superfície são muito vivazes e claros, mas nas profundezas são tranquiilos e obscuros..."(p. 37). A imagem do crocodilo é duplicada também na história, pelo jacaré, um símile da canoa quando ela deixa a margem carregando o pai para o meio do rio: "E a canoa saiu se indo - a sombra dela por igual, feito um jacaré, comprida longa" (p. 409). A transmigração de jacaré-canoa da história para o crocodilo da entrevista ilustra dois momentos distintos do mesmo. A transmigração ocorre quando uma alma imperfeita volta ao mundo material dentro de um novo ser para rememorar e reaprender e assim completar, tantas vezes quanto seja necessário, seu caminho para a perfeição. A morte traz esquecimento e o conhecimento não passa de rememoração. A teoria platônica explica assim porque o jacaré imperfeito tem que relembrar sua condição de crocodilo, signo de sua perfeita adaptação no rio da eternidade em seu caminho para a perfeição. O crocodilo vive no rio como se este fosse um oceano de sabedoria. Mas a canoa é tambémo jacaré, em sua sombra, um outro termo inserido na história, de claras conotações platônicas. E, como crocodilo, escolhe o meio do rio da sabedoria e do eterno. O filho, este sim, teme acabar com a vida nos "rasos" do mundo, enquanto o pai estabelece-se no profundo do rio. 


\section{DE SOMBRAS}

A imagem do jacaré-canoa como sombra acrescenta-se ao tema da ausência do pai. Sua natureza de sombra é parte do mistério indecifrável da morte. Depois de cruzar o Letes e o Estige, a sombra daquele que morreu é recebida por outras sombras no reino de Hades. Lembremos que as sombras, entretanto, não vão voluntariamente para lugar algum, mas são conduzidas, primeiro por Hermes, psicopompo, condutor de almas, depois por Caronte. Almas e sombras não possuem vontade por isso não tomam iniciativas. Os mortos não vão a nenhum lugar. Algo lhes acontece. A morte é sempre algo passivo: "Nosso pai não voltou. Ele não tinha ido a nenhuma parte. Só executava invenção de se permanecer naqueles espaços do rio, de meio a meio, sempre dentro da canoa, para dela não saltar, nunca mais" (p. 409). Não voltar sem ter ido a parte alguma, permanecer nos espaços do rio dentro da canoa. Se nossa tentativa de interpretação da canoa como um caixão for aceitável, então as palavras que descrevem os eventos em torno do que aconteceu ao pai são de uma literal precisão.

Junto com o símile do jacaré e o simbolismo do crocodilo, o rio, que é um oceano de sabedoria, absorve a sombra do pai numa metamorfose final. A dissolução da morte se torna positiva porque morrer, de fato, é deixar a esfera do individual para ser reabsorvido pelo grande ser de novo. Nesse sentido, o rio do esquecimento é também o rio da sabedoria. A sombra da canoa, portanto, ao igualar-se ao jacaré, revela sua própria natureza.

O rio, em uma de suas manifestações, é o rio do esquecimento: “ “.. Largo, de não se poder ver a forma de outra beira” (p. 409). Não se poder ver as formas é uma afirmativa também ligada à morte. Como sombra, forma também é uma palavra platônica. Os habitantes da caverna não são capazes de ver as formas puras, apenas suas sombras.

A largura do rio é algo que aponta para o ilimitado. As margens oferecem limites, contêm um rio. Esse rio é tão largo que não se vê a outra beira. Se o rio é largo e ilimitado, não se pode ver a outra beira, pode ser um indício de impossibilidade, um limite na alçada de visão de quem olha.

\section{DE AUSÊNCIAS}

A ausência do pai na história é, de fato, sentida muito antes de sua ação tida como inusitada pela família. Ela está avançada, por exemplo, no silêncio que esconde o seu plano. Será que a canoa serviria para pescar ou caçar? "Nosso pai nada não dizia" (p. 409). A dupla negativa, comum na linguagem popular, sofre aqui uma inversão barroca, sublinhando as questões metafísicas em jogo na frase. Nosso pai não dizia algo, portanto escondia algo. Nosso pai não dizia nada, portanto dizia, sem dizer, alguma coisa que não se compreendia. Nosso pai dizia o nada, punha diante de nós o nada. É, aliás, nesse sentido que Heidegger (5) compreende o verbo dizer em grego (legein). Dizer é colocar-diante-de. Nesse sentido, o pai coloca diante do filho o nada. O que é reveladoé o desvelamento do nada, a aletéia do vazio. A dupla negativa também permite uma interpretação que afirma e nega ao mesmo tempo. Ela afirma, como vimos, a substância nada do nada, a tutaméia. O pai disse o nada contido na idéia de nada. Porém ela nega também o nada enquanto pura aniquilação. Estamos de volta ao quarto escuro, com o gato preto que não está lá.

\section{DO FLUXO DO TEMPO, DE PAIS E SOMBRAS}

Em "Viagem na Família” (6), um dos vários poemas sobre o silêncio do pai, Drummond de Andrade repete no fim de quase todas as estrofes: "Porém nada dizia". A relação entre o poeta e a sombra de seu pai, mal escondendo uma inspiração 
hamletiana, baseia-se num esquema atemporal em que o laço entre o filho e o pai é finalmente estabelecido: "Só hoje nos conhecermos!" Essa relação entre sombra e ser só pode acontecer, entretanto, no tempo do desejo que é o tempo da eternidade. A eternidade enraíza a possibilidade imaginária, fazendo-a acontecer nesse fortuito momento que une o passado, o presente e o futuro que é o tempo da eternidade e o tempo do desejo, onde tudo pode acontecer.

O silêncio do pai é a fonte da fala do filho. Da mesma forma, o narrador em Rosa também escreve para entender, para buscar perdão. A sombra do pai em Drummond, afora a sua inclinação hamletiana, condensa outras imagens de associação entre sombras e vivos, como Orfeu e Eurídice ou Dante e Virgílio. A sombra do pai em Drummond, entretanto, não vem clamar vingança ou atormentar o filho com mais culpas. A relação desse pai-sombra e desse filho-vivo se dá numa paisagem de possibilidades mínimas: o deserto de Itabira, não era dia nem noite, e o tempo mastiga os mortos. Aquilo que não foi dito ou articulado foi o amor que uniu pai e filho, agora retornando e clamando por uma reconciliação.

"Olhei-o nos olhos brancos.

Gritei-lhe: Fala! Minha voz

vibrou no ar um momento,

Bateu nas pedras. A sombra

prosseguia devagar

aquela viagem patética

através do reino perdido.

Porém nada dizia”.

As imagens da sombra do pai, seu silêncio, e a "viagem patética" estão também presentes na história de Rosa. O narrador de "A Terceira Margem do Rio" também viaja na família e mergulha no silêncio paterno. Mas a progressão do poeta difere daquela do narrador em Rosa. O pai do poeta é agora uma sombra e a evolução dos acontecimentos entre pai e filho projeta o encontro no atemporal, o que possibilita o resgate final entre eles, sub aespecie aeternitates.
“A pequena área da vida me aperta contra o seu vulto, e nesse abraço diáfano é como se eu me queimasse todo, de pungente amor.

Só hoje nos conhecemos!

Óculos, memórias retratos fluem no rio do sangue.

As águas já não permitem distinguir seu rosto longe, para lá de setenta anos...

Senti que me perdoava porém nada dizia.

As águas cobrem o bigode, a família, Itabira, tudo".

\section{DAS DUAS MARGENS DO RIO}

O rio na história de Rosa são as águas que cobrem tudo em Drummond, no dilúvio final de seu poema. O rio é o rio de sangue que liga ambas as gerações. As muitas gerações formando a interminável cadeia de pais e filhos se interrompe na história de Rosa porque o narrador é um homem sem filhos. Ao mesmo tempo, ele é o porta-voz da coletividade anunciando que também fala pela espécie. O rio na história de Rosa é o tempo perpétuo enquanto as águas de Drummond estão imersas no eterno.

A narração na clave do nós enfatiza a idéia de historicidade e mortalidade presente no indivíduo que fala pelo coletivo de sua espécie. Mas o rio que ele enfrenta é o rio da unidade e do tempo perpétuo, o motocontínuo do tempo. Há aí uma relação de tensão entre o indivíduo que sofre os efeitos do tempo, sempre sujeito às suas mudanças, envelhecendo, morrendo, e a possibilidade de ser, de novo, recolhido pelo rio da eternidade.

Esse rio, portanto, em uma de suas margens escoa-se no perpétuo fluxo do tempo, aquele rio que jamais é o mesmo, estando em contínuo movimento heraclitiano. Mas esse rio é também o rio da 
imutabilidade porque seu tempo só transcorre, só é real, na verdade, para o ser-paraa-morte que se vê aprisionado em suas águas, numa canoinha de nada. Esse rio é também o eterno. Esse rio dual, de duas margens, eterno e mutável se manifesta em seus rasos e profundos apenas quando suas duas margens se definem. Mas onde se situa essa terceira margem do rio?

\section{DE TERCEIRAS MARGENS}

Voltando ao poema de Drummond, há o sutil sentimento de culpa que impregna a relação do poeta com seu pai. As águas encobrem as feições paternas, agora perdidas numa distante memória. As águas do tempo cobrem tudo, escondendo as lembranças do poeta no rio do esquecimento. À diferença do poeta, o narrador em Rosa se encontra em estado de confusão, submerso em culpa. O poeta sente que o pai o perdoa: "Senti que me perdoava", mas o pai nada dizia. Sentir o perdão do pai tem uma força arrebatadora que neutraliza qualquer outro sentimento, inclusive o de culpa. O poeta sabe que foi perdoado, embora os motivos que levaram o pai ao perdão sejam deliberadamente vagos no poema, esquivos, talvez por serem demasiado desimportantes. Perdoar e sentir o perdão é oque o poema nos traz. O narrador em Rosa, entretanto, pede três vezes para ser perdoado, depois de todos os anos de silêncio paterno.

Na história de Rosa não há pacto, nenhuma pacificação é atingida, nenhum resgate alcançado. Pelo contrário, o narrador é aprisionado na perpetuidade do fluxo do tempo: "e eu, rio abaixo, rio afora, rio adentro-o rio" (p.413). Como se ele se tornasse o próprio rio, como se o rio se tornasse interior, essencial, inseparável de sua própria condição, como na epígrafe de Borges que citamos: "El río me arrebata y soy ese río".

Tanto em Drummond quanto em Rosa a possibilidade ou impossibilidade de resgate são narradas sob o ponto de vista do filho. O estado de culpa assombra a ambos. Mesmo se de novo trouxermos o motivo antropológico-freudiano do assassínio primordial do pai por seus filhos como o elemento gerador da culpa, estaremos aí muito mais introduzindo um enigma doque resolvendo um outro. Nem será preciso entrar na questão da acuidade histórica da hipótese, irrelevante para a análise em questão. Talvez, se encararmos a hipótese como uma metáfora da relação primordial entre pai e filho, um mythos, no sentido aristotélico do termo: uma historieta que explica o inexplicável, possamos prover essa relação de culpa com alguma penetração. O assassínio, nessa versão metafórica, nem precisa ter ocorrido, ele vira mais um símbolo de negatividade ou de denegação de um cenário inicial concebido pela mente, autoridade e poder paternos. É quase possível se dizer que, dentro dessa versão, ocorrem as três fases da história hegeliana: um primeiro momento quando o filho está sujeito à lei paterna (tese), um segundo momento em que ele se rebela (antítese) e a última fase quando ele finalmente procura dissolver o resto do conflito através de formas de identificação, fusão e resgate (síntese). O conto de Rosa termina quando, procurando dissolver o seu conflito de culpa, o filho busca o perdão mas não sabe se foi perdoado. $O$ poeta de "Viagem na Família" passa incólume pelas três fases.

\section{DA PROFUNDIDADE DAS SUPERFIIIES}

Dos rasos do mundo à superfície dos rios que são vivazes e claros, deixando que em suas profundezas sejam "tranqüilos e obscuros como os sofrimentos do homem", o "rio é uma palavra mágica para conjugar eternidade" (p. 37). A superfície das águas em sua vivacidade, em “A Terceira Margem do Rio", é o ponto de contato, o ponto de sustentação entre a canoa do indivíduo e as profundezas do sofrimento do homem. É 
portanto na superfície que se dá o encontro entre rio e homem. É este o ponto no espaço onde a mortalidade do individual encontra a imortalidade e eternidade do rio.

Éna superfície que o microcosmo se une ao macrocosmo. No conto "São Marcos", da coletânea Sagarana (7), o narrador do conto vê "o retrato invertido de todas as plantas tomando um banho verde no fundo... E a lagoa parece dobrada em duas, e o diedro é perfeito" (p. 371). Segundo a primeira lei do hermetismo, dita da Tábua de Esmeralda, aquilo que está em cima é igual àquilo que está embaixo. Esse princípio se repete na forma do signo de Salomão, ou a estrela de seis pontas, onde o triângulo de ponta para baixo, signo do macrocosmo, se une ao triângulo de ponta para cima, que representa o microcosmo. Essa lei procura dimensionar a interação entre universo e natureza afirmando que todos os mundos funcionam sob uma mesma lei do eterno. O percebedor dessa medida será o homem, a superfície onde se dá a compreensão do princípio, a percepção do uno e do eterno no múltiplo e mutável. Se continuarmos com a imagem da paisagem do macrocosmo projetada no microcosmo da água, veremos que é, também, na superfície que a união se dá. No reflexo, pois o macrocosmo é o reflexo do microcosmo e vice-versa. A superfície é, então, o ponto espacial onde a fusão dessas duas esferas acontece. O rio em eterno fluxo do tempo corre indiferente, com seus crocodilos, magisters da metafísica, conjugando a eternidade.

Entretanto, a canoa do indivíduo, ao tocar a água, apaga o espelho do universo, anuvia as águas, quebra a harmonia invertida assim como a historicidade individual rompe com a harmonia impessoal do universo. Essa canoa parada, na terceira margem do rio, sua superfície, entretanto, restabelece a jornada humana de volta ao atemporal, ao eterno do rio-fluxo-temporal. A superfície pode muito bem sero ponto de junção entre as duas esferas, como se a terceira margem constituísse sua interface.

A terceira margem do rio pode muito bem ser o lugar do não-lugar, uma forma radical de utopia onde o lugar do não-lugar encontra o tempo do não-tempo. Pode ser o encontro entre o eterno e o mortal, ou o histórico e o universal. Ela pode ser também o ponto de encontro onde o indivíduo se dissolve no Uno (8).

Heráclito, no fragmento B 16, se pergunta: "Como pode um esconder-se diante daquilo que nunca se põe?” (9). O rio nunca se põe, como um eterno sol. Como pode esse um, esse alguém cuja essência, sendo parte desse grande universo, esconder-se daquilo que the constitui? Um pai numa canoa que lhe serve e a mais ninguém se põe no rio, nas mãos daquilo que lhe pertence, pois nunca deixou de the pertencer, sendo parte de seu ser. Por um tempo desviado, nos caminhos da história individual, o ser apenas encontra a si, de novo, na terceira margem desse rio, desse lugar de não-lugar, nesse tempo de nãotempo. A terceira margem do rio é feita da mesma substância nada de que são feitos ossos-de-borboleta: tutaméia.
7 João Guimarães Rosa, Sagarana, op. cit., vol. I.

8 Em cópia preservada de sua biblioteca, Rosa sublinhou a seguinte passagem de Musings of a Chinese Mystic: "Life follows upon death. Death is the beginning of life. Who knows when the end is reached? The life of man results from convergences of the vital fluid. Its convergence is life; its dispersion, death. If, then, life and death are but consecutive states, what need have I to complain? Therefore all things are One. What we love is animation. What we hate is corruption. But corruption in its turn becomes animation, and animation once more becomes corruption" |"A vida segue-se à morte. A morte é o início da vida. Quem sabe quando o fim éalcançado? A vida do homem resulta de convergências do fluido vital. Sua convergência é vida, sua dispersão, morte. Se, portanto, vida e morte não passam de estados consecutivos, que necessidade tenho eu de reclamar? Portanto tudo Um. O que amamos é animação. $\mathrm{O}$ que detestamos é corrupção. Mas a corrupção por sua vez se torna animação e a animação uma vez mais se torna corrupção")

9 Martin Heidegger, "Aletheia (Heraclitus, Fragment B 16)", in op. cit., p. 105 